\title{
ESTROGEN AND PROGESTERONE PROFILES DURING SUPEROVULATION IN BUFFALO HEIFERS WITH HIGH AND LOW OVULATORY RESPONSE
}

\author{
A.M. OSMAN* and S.H. SHEHATA \\ *Department of Theriogenology, Faculty of Veterinary Medicine, Assiut University, Assiut, Egypt.
}

\section{ABSTRACT}

Received at: 24/11/2012

Accepted: 27/1/2013
Fifteen buffalo heifers of similar age and weight investigated during mid-luteal phase. Ten superovulated with pFSH (65 NIH units, Super-Ov, divided into 6 equal doses, injected for 3 consecutive days) and $25 \mathrm{mg}$ Lutalyse given with fifth injection. LH (2000 USP unit) injected 12 hour (h) from treatment. Rest 5 heifers kept as control. Blood samples taken before treatment (Oh) then after 12, 24, 48, 72, 96, 120 and $144 \mathrm{~h}$. Sera collected and kept at $-20 \mathrm{C}^{\circ}$ for estrogen (e) and progesterone (p) determinations using Enzyme Immunometric Analyzer. Superovulated heifers slaughtered after last blood samples to count corpora lutea (CL) and unovulated follicles (UF). Oviducts and uterus flushed to recover embryos. Results classified into high response group (HRG) $>2 \mathrm{CL}(3.8 \pm 0.49)$ and low response group $(\mathrm{LRG})<3 \mathrm{CL}(1.2 \pm 0.2)$. Nine embryos recovered from HRG where significant increase in e noticed at $72 \mathrm{~h}$ followed by marked decrease. The increased e in LRG continued till last sample with significant difference $(\mathrm{P}<0.05)$. The total number of UF was significantly lower $(\mathrm{P}<0.05)$ in HRG. The overall $\mathrm{p}$ levels $(\mathrm{ng} / \mathrm{ml})$ were significantly lower $(\mathrm{P}<0.01)$ in $\mathrm{HRG}$ than $\mathrm{LRG}$ and control. Lutalyse induced significant reduction in $\mathrm{p}$ after 2 days from injection in HRG only. Wide variations in $\mathrm{p}$ levels $(\mathrm{ng} / \mathrm{ml})$ were noticed in buffalo heifers at the start of treatment, during mid luteal phase and low concentrations reported with HRG $(0.87 \pm 0.33)$. Therefore, low levels of $\mathrm{p}$ at the beginning of superovulation could indicate successful ovulatory response.

Key words: Estrogen, progesterone, superovulation, response

\section{INTRODUCTION}

Superovulation is a topic of great interest in animal reproduction since many of the literature showing a contrasting superovulatory response.

Uoc et al. (1997) showed that the supplementation of estrogen and human chorionic gonadotropin treatment significantly improved the level of ovarian stimulation in Swamp buffalo. The same authors declared that the level of ovarian stimulation in buffalo is still unpredictable and low. Osman et al. (2001) reported that 2000 USP unit chorionic gonadotropin injected at the $5^{\text {th }}$ day of treatment improved the rate of ovulation in buffalo cows rather than in buffalo heifers when superovulated with pFSH administered for 3 consecutive days. Donaldson (1985) mentioned that neither ovarian size, number of corpora lutea nor blood progesterone levels were correlated with embryo production.

The suppressive effects of dominant follicle and as well the endocrine disorders are among the factors affecting superovulatory response in cattle (Kafi and
McGowan, 1997). Moreover, Madan et al. (1996) concluded that UF at superovulation contribute high quantity of estrogen altering the uterine milieu. Beg et al. (1997) declared that no significant difference was observed in ovulatory response of buffalo superovulated in mid or late luteal phase (days 8-12 or 13-15 of the estrous cycle). Mervat (2007) attributed the presence of follicles with variable sizes during all phases of estrous cycles to the continuous process of folliculogenesis in buffaloes.

Roberge et al. (1995) cited that in superovulated Holstein heifers, 30 hour after prostaglandin treatment, serum estradiol concentration and $\mathrm{LH}$ pulse frequency were positively correlated with the number of $\mathrm{CL}$, total number of embryos and transferable number of embryos recovered. In superovulated cows, the suppression of LH and FSH secretion was caused by the negative effect of higher concentrations of estradiol and progesterone in the hypothalamic-hypophysial axis (Roberge et al., 1995 and Pant, 2000).

Positive correlation between superovulation and plasma progesterone at the time of gonadotropin 
treatment has been demonstrated in buffalo (Madan et al., 1993) and cattle (Gradela et al., 1996 and Beg et al., 1997). However, Greve et al. (1983) and Lindsell et al. (1986) claimed to the contrary in cattle. Misra et al. (2000) found that concentration of progesterone on the day of superovulatory treatment and estrogen concentration on day 2 of superovulatory cycle were positively correlated with ovulation rate. McEvay et al. (1996) cited that neither feed restriction nor supplementary progesterone prior to ovulation influence the proportionate yields of viable embryos at day 7 after estrus in Simmental heifers.

Ismail et al. (1992) and Misra et al. (2000) indicated that measurement of circulating progesterone at the start of gonadotropin injection may be a useful index of superovulatory response and embryo recovery in multiparous buffalo cows and high levels of progesterone gave better results.

The present work aimed to throw some lights on the event of changes occurring in the blood serum estrogen and progesterone during superovulation in buffalo heifers with contrasting high and low superovulatory response as a trial to predict the success of ovarian stimulus at the start of superovulation.

\section{MATERIALS and METHODS}

From a local governmental buffalo farm, 15 heifers at mid luteal phase (day 10-12 of the estrous cycle) were selected. These animals were healthy and raised under the same environmental condition of management and feeding. They aged 21-25 month and weighed $325-385 \mathrm{~kg}$. Ten heifers of them were superovulated with pFSH (Total 65 NIH unit, SuperOv, divided into 6 equal doses, injected for 3 consecutive days) and Lutalyse (25 $\mathrm{mg}$ given with the fifth injection). LH doses (2000 USP unit) were injected 12 hour from $\mathrm{pFSH}$ treatment. The amount of pFSH which used in the present investigation was applied according to the recommendation of Osman et al. (2001) for buffalo heifers. The rest 5 heifers were injected with saline and served as control.

Blood samples were taken from the jugular vein just before treatment ( 0 hour) then after $12,24,48,72,96$, 120 and 144 hour. After clotting and centrifugation, sera were collected and kept at $-20 \mathrm{C}^{\circ}$ for e and $\mathrm{p}$ determinations using Immulite Enzyme Immunometric Analyzer (Randolf, N.J., USA).

All heifers were slaughtered, just after the last blood sampling, and their genitalia were taken to the laboratory for further investigations. The numbers of newly formed CL and UF were taken. Moreover, all
UF were measured to the nearest $1 / 10 \mathrm{~cm}$. using a metal caliber. Flushing of the oviducts and uterine horns were made with saline to count the recovered embryos using a stereo microscope.

The obtained data were statistically analyzed using the student t-test and simple correlations between two factors according to SAS computer system version 3.2 and Snedecor (1980).

\section{RESULTS}

The obtained results are presented in tables 1-3. The number of new CL and UF $(<0.8 \mathrm{~cm})$ showed significant difference $(\mathrm{P}<0.05)$ between $\mathrm{HRG}$ and LRG (Table 1). Moreover, embryos were recovered only from HRG. Although these animals were selected during mid luteal phase and were nearly similar in age and live body weight, at the start of superovulation, varying degrees of ovarian response were observed at the end of the treatment.

Estrogen profiles (Table 2) showed insignificant changes between groups, although the overall mean was higher in the superovulated heifers than control (28.26 $\pm 4.1 \mathrm{pg} / \mathrm{ml}$ versus 25.62 $\pm 3.6 \mathrm{pg} / \mathrm{ml}$ respectively). The higher levels reported for estrogen in HRG than LRG and control at 24, 48 and $72 \mathrm{~h}$ from FSH injection were accompanied with higher incidence of ovulation and CL formation. Moreover, within $\mathrm{HRG}$, there was a significant increase $(\mathrm{P}<0.05)$ in estrogen level at the time of LH injection after 72 hour (onset of estrus) from treatment followed by marked decrease till the end of trial at 144 hour. This decrease coincides with the observed low number of small UF ( $<0.8 \mathrm{~cm}$, Table 1$)$. The reverse was true within the LRG in which significant increase in e was observed between 96 and 144 hour of the treatment when a significant increase in the number of small UF was noticed without any recovered embryos after flushing the uterine horns and oviducts.

During the last 2 days of the study, at 120 and 144 hour, significant correlation was present between the number of large UF $(>0.7 \mathrm{~cm})$ and e levels in treated groups $(\mathrm{r}=0.65, \mathrm{P}<0.05)$. One day after $\mathrm{LH}$ injection, e levels decreased in all treated animals. The total number of UF in LRG was 37 versus 23 in HRG.

Out of table 3, significant $(\mathrm{p}<0.01)$ low concentrations of $\mathrm{p}$ were reported with HRG $(0.87 \pm 0.33)$ in comparison with the LRG $(3.67 \pm 1.25)$ and control $(1.57 \pm 0.23)$ at the first day of injection. These low levels of $\mathrm{p}$ in the HRG remained lower till the last day of treatment. Moreover, the overall $p$ levels were significantly lower $(\mathrm{P}<0.05)$ in $\mathrm{HRG}$ than the other two groups $(0.86 \pm 0.15$ versus $2.97 \pm 0.38$ LRG and $2.3 \pm 0.21$ control). It is evident that heifers with low levels of $\mathrm{p}$ at the start of superovulation responded much better for superovulation than the others. 
Lutalyse induced significant reduction in $\mathrm{p}$ levels after 2 days in HRG only (between 12 and 96 hour, $\mathrm{P}<0.05)$. Significant correlation between $\mathrm{p}$ and $\mathrm{CL}$ was present among treated groups, during the last 2 days of treatment $(\mathrm{r}=0.85, \mathrm{P}<0.01)$. The continued decrease in $\mathrm{p}$ till the end of study, after Lutalyse injection, in the LRG, reflected the decreased number of successful ovulation with a consequent low number of new CL.
The average increase in $\mathrm{p}$ during the last 2 days of treatment in relation to the previous days were 2.27 fold in HRG versus 0.54 fold increase in LRG and 1.27 in control group. With regard to e such pattern of increase showed contrary results: 0.75 fold increase in HRG versus 1.21 fold in LRG and 0.87 fold in control group. Marked increase in $\mathrm{p}$ accompanied with marked decrease in e during the last 2 days of treatment (Day of embryo collection) could reflect high ovarian response to superovulation and embryos yield.

Table 1: Distribution of New Corpora Lutea, Unovulated Follicles and Recovered Embryos in High and Low Response Superovulated Buffalo Heifers.

\begin{tabular}{|c|c|c|c|c|}
\hline $\begin{array}{l}\text { Superovulated } \\
\text { Buffalo Heifers }\end{array}$ & New Corpora Lutea & $\begin{array}{l}\text { Unovulated Follicles } \\
\qquad(>0.7 \mathrm{~cm})\end{array}$ & $\begin{array}{l}\text { Unovulated Follicles } \\
\qquad(<0.8 \mathrm{~cm})\end{array}$ & Recovered Embryos \\
\hline $\begin{array}{l}\text { High Response } \\
\text { Group }\end{array}$ & $3.8 \pm 0.49 *$ & $1.6 \pm 0.51$ & $3.0 \pm 0.77 *$ & $1.8 \pm 0.76$ \\
\hline $\begin{array}{l}\text { Low Response } \\
\text { Group }\end{array}$ & $1.2 \pm 0.20$ & $1.0 \pm 0.32$ & $6.4 \pm 0.68$ & 00.00 \\
\hline
\end{tabular}

$\mathrm{N}=5$

Mean \pm SEM

* Significant $(\mathrm{P}<0.05)$ within column

Table 2: Estrogen Profile ( pg / ml ) During Superovulation in Buffalo Heifers with Variable Ovarian Response

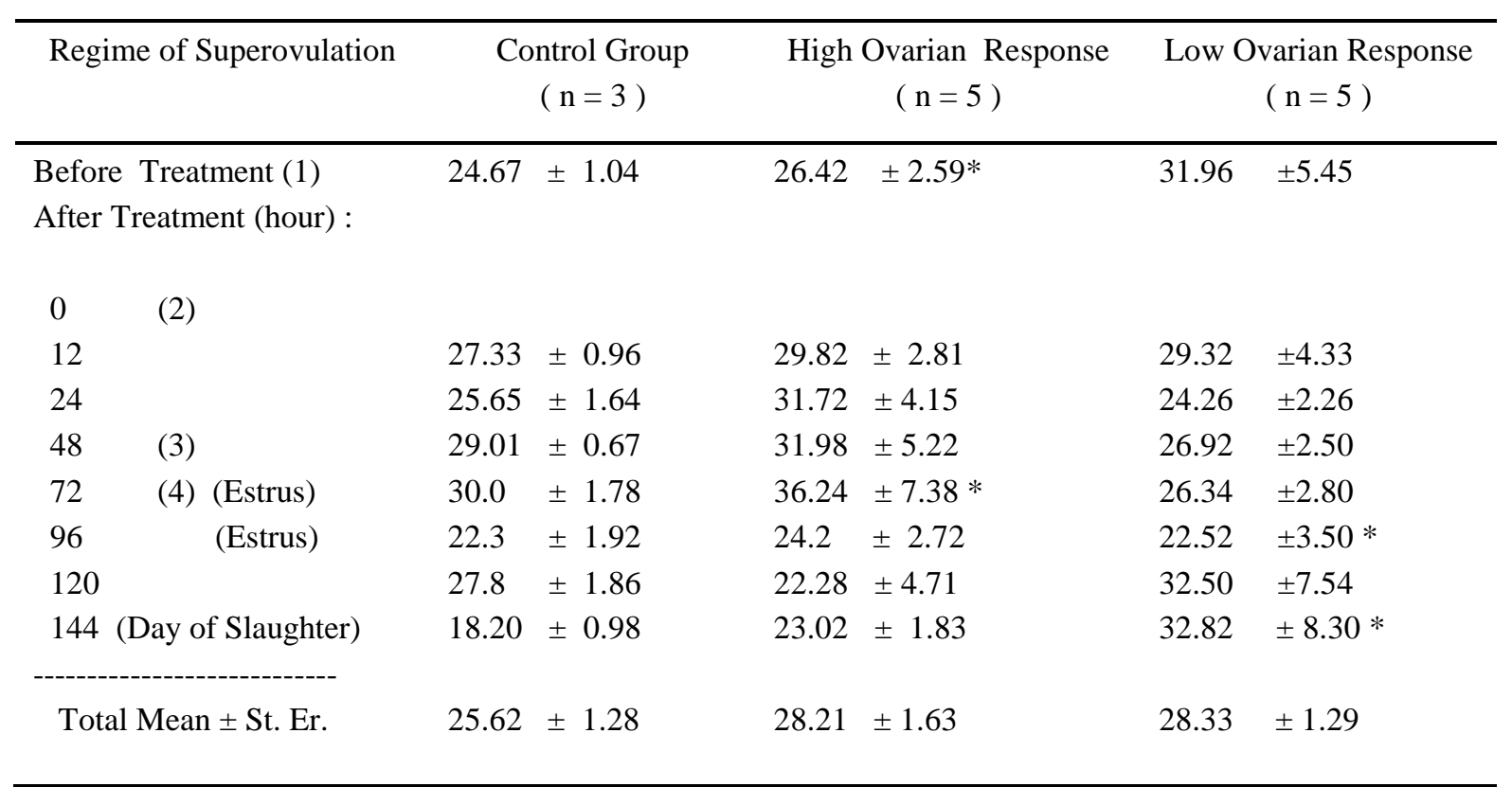

\footnotetext{
Mean \pm SEM

(1) At Mid-luteal phase

(1) pFSH Injection

(2) Lutalyse Injection

(3) LH Injection

High Response Group : Ovaries with > $2 \mathrm{CL}$

Low Response Group : Ovaries with $<2 \mathrm{CL}$

* Significant Difference within Group $(\mathrm{P}<0.05)$
} 
Table 3: Progesterone Profile ( $\mathrm{ng} / \mathrm{ml}$ ) During Superovulation in Buffalo Heifers with Variable Ovarian Response.

\begin{tabular}{|c|c|c|c|c|c|c|}
\hline Regime of Superovulation & \multicolumn{2}{|c|}{ Control Group } & \multicolumn{2}{|c|}{$\begin{array}{l}\text { High Response Group } \\
\text { Ovaries with }>2 \mathrm{CL}\end{array}$} & \multicolumn{2}{|c|}{$\begin{array}{l}\text { Low Response Group } \\
\text { Ovaries with }<2 \mathrm{CL}\end{array}$} \\
\hline Before Treatment (1) & 1.57 & $\pm 0.23 *$ & 0.87 & $\pm 0.33 *$ & 3.67 & $\pm 1.25 *$ \\
\hline \multicolumn{7}{|l|}{ After Treatment (hour): } \\
\hline $0 \quad(2)$ & & & & & & \\
\hline 12 & 1.47 & \pm 0.19 & 1.04 & $\pm 0.21 *$ & 4.86 & $\pm 1.33 *$ \\
\hline 24 & 1.63 & \pm 0.19 & 0.88 & \pm 0.34 & 4.34 & \pm 1.28 \\
\hline $48 \quad(3)$ & 2.73 & \pm 0.17 & 0.32 & $\pm 0.12 *$ & 2.16 & $\pm 0.54 *$ \\
\hline 72 (4) (Estrus) & 2.80 & \pm 0.22 & 0.57 & $\pm 0.23 *$ & 2.46 & $\pm 0.64 *$ \\
\hline (Estrus) & 2.77 & \pm 0.15 & 0.25 & \pm 0.03 & 2.40 & \pm 0.89 \\
\hline 120 & 2.93 & \pm 0.26 & 1.46 & \pm 0.59 & 2.0 & \pm 1.63 \\
\hline 144 (Day of slaughter) & 2.58 & \pm 0.25 & 1.52 & \pm 0.83 & 1.86 & \pm 0.71 \\
\hline Total Mean & 2.31 & \pm 0.21 & 0.86 & \pm 0.15 & 2.97 & \pm 0.38 \\
\hline
\end{tabular}

$(\mathrm{N}=5)$ Mean $\pm \mathrm{SEM}$

(3) Lutalyse Injection

(1) At Mid-luteal phase

(4) LH Injection

* Significant Difference between groups $(\mathrm{P}<0.05)$

* Significant difference within HRG between 12 and 96 hour $(\mathrm{P}<0.05)$
(2) $\mathrm{pFSH}$ Injection

\section{DISCUSSION}

Although the investigated buffalo heifers were selected during mid luteal phase, at the start of superovulation, varying degrees of ovarian response was observed at the end of treatment. This means great individual variations in reaction of the ovaries to superovulation in buffalo heifers even with nearly similar ages, body weight and other managerial conditions of breeding. Our attention to classify heifers into high and low response groups based on the wide variations of the obtained results. Kafi and McGowan (1997) and Mohammed (2000) cited about the variability of the superovulatory response in cattle and buffalo to be a primer difficulty in successful embryo transfer program.

The obtained results with regard to ovulations and number of recovered embryos agree with those published by El Sherry (2003) in superovulated buffalo heifers, but much less than those reported in dairy cattle by Feuntes and De La Fuente (2000) who recovered $12.8 \pm 7.5$ embryos from superovulated Holstein heifers. Drost (2007) attributed the much lower rate of success in embryo transfer techniques in water buffaloes than those in cattle to their inherent lower fertility and poor superovulatory response. Moreover, Presicce et al. (2004) concluded that many significant morphological and endocrine differences were present between nuliparus and mixed parity
Mediterranean Italian buffaloes following estrus synchronization.

Estrogen profiles showed insignificant differences between groups, although the overall mean was higher in the superovulated heifers than control $(28.26 \pm 4.1 \mathrm{pg} / \mathrm{ml}$, versus $25.62 \pm 3.6 \mathrm{pg} / \mathrm{ml}$, control). These findings coincide with the results of Sunilchandra et al. (2001) who reported that peak estradiol concentration was significantly greater in buffalo treated with follicle stimulating hormone than that of control. Within HRG, there was a significant increase $(\mathrm{P}<0.05)$ in $\mathrm{e}$ level at the time of $\mathrm{LH}$ injection after $72 \mathrm{~h}$ from treatment (during estrus) followed by marked decrease till the end of trial at $144 \mathrm{~h}$ (Day 6). This decrease could be attributed to the observed low number of small UF (less than 0.8 $\mathrm{cm}$, Table 1) since the other larger follicles ovulated. Roy and Parkash (2008) found that estrus behavior was positively correlated with peak concentration of estradiol-17 $\beta$ and total e, during the peri-estrus period in buffalo heifers with induced ovulation. The higher levels of e in HRG than LRG and control at 24, 48 and $72 \mathrm{~h}$ from FSH injection were accompanied with improved rate of ovulations. Thus, high levels of e during this period may be essential for successful superovulation.

In LRG the significant increase in e was observed between 96 and 144 hour of treatment when a significant increase in the number of small UF was 
noticed without any recovered embryos. The circulating estrogen in the same group reached a peak level at day of slaughter. Within the scope of these findings, Roy and Parkash (2008) found that estrus behavior was positively correlated with peak concentration of estradiol-17 $\beta$ and total e, during the peri-estrus period in buffalo heifers with induced ovulation.

It might be possible that estimation of e at the day of embryo collection (Day 6) in buffalo heifer can be used as a criterion to predict the success of superovulation and yield embryos since high levels of estrogen at this day were accompanied with poor ovulation rate.

In the present work, peak estrogen concentration $(32.82 \pm 8.3 \mathrm{pg} / \mathrm{ml})$ was noticed at day of slaughter (144 hour from treatment) in LRG where the highest number $(6.4 \pm 0.68)$ of small UF (less than $0,8 \mathrm{~cm}$ ) was recorded (table 1). This may lead us to conclude that UF of variable size could contribute more estrogen to the animal during superovulation. The present results are in agreement with Madan et al. (1996). However, Ginther et al. (2000) reported that in cattle the largest follicles release estradiol into the blood at the beginning of follicle deviation during the mid-luteal phase. On the other hand, Gibbons et al. (1999) reported that 5-mm follicles were not associated with increased estradiol levels in cattle. The day of follicle deviation was reported by El Sherry (2003) to be the $10^{\text {th }}$ day of estrous cycle in buffalo heifers. Thus, the dominant follicle may play a role in the high level of e at this period in which the present trial was started.

In HRG, the superovulated heifers reacted more satisfactory with the FSH gonadotropin treatment since the levels of e were higher, during injections, than other groups. Such high levels of e may be required for the full growth of the developed follicles and as well for their ovulations and CL formations. In LRG where the e levels were lower during the first 2 days of treatment, the total number of UF was higher (37 versus 23 in HRG). Fuentes and De La Fuente (2000) used exogenous estradiol plus $p$ to improve embryo production in superovulated Holstein dairy herds.

The significant differences in $\mathrm{p}$ levels between groups at the start of treatment indicate wide individual variations in the functional activity of CL during mid luteal phase in buffalo heifers. Moreover, animals with low levels of $p$ at the beginning of superovulation responded much better than others. It is noticed here that week response of the ovaries for superovulation is expected to occur when buffalo heifer has a high concentration of $\mathrm{p}$ at the beginning of the regime. Misra et al. (2000) reported contrasting results in buffalo cows.
The overall concentrations of $\mathrm{p}(\mathrm{ng} / \mathrm{ml})$ were significantly lower in HRG than control $(0.86 \pm 0.15$ versus $2.97 \pm 0.38)$. Within the scope of this area, El Sherry et al. (2011) cited that the superovulated CL has a smaller size, shorter lifespan and less P production in comparison with the cyclic CL.

The significant reduction in progesterone levels, after 2 days from Lutalyse injection in HRG only (between 12 and 96 hour, $\mathrm{P}<0.05$ ) concomitantly run with the initial low levels of this hormone at the start of treatment. This may indicate rapid autolysis of the weekly active CL, which secretes low p during mid luteal phase in buffalo heifers, in response to Lutalyse treatment. Such marked autolysis of the CL may play a role in the success of superovulation in HRG. In agreement with these results, El Sherry et al. (2010) reported that low $\mathrm{p}$ level during FSH treatment enhanced multiple follicular growth and estradiol secretion. They added that absence of CL may play a critical role in the superovulation response by controlling the number of growing follicles.

Significant correlation between progesterone and corpora lutea was present among treated groups, during the last 2 days of treatment. In HRG progesterone showed significant increase $(\mathrm{r}=0.85, \mathrm{P}<$ 0.01 ) after $72 \mathrm{~h}$ (estrus period) in association with the newly formed CL. Although positive correlation between superovulatory response and plasma progesterone at the time of gonadotropin treatment has been demonstrated in buffalo by Madan et al. (1993), Ullah et al. (1992) claims to the contrary in Nili-Ravi buffalo.

During the last 2 days of treatment the mean p levels were nearly double that before treatment in HRG and the reverse was true in LRG. These findings coincide with Papa et al. (2007) who reported that in superovulatory buffalo the CL is able to increase the translation rate of the vascular endothelial growth factor of the luteal cells to produce progesterone.

On the other hand, the continued decrease in progesterone till the end of study, after Lutalyse injection, in LRG, reflected the decreased rates of successful ovulation and CL formation.

It is evident from table 3, that the lowest levels of $\mathrm{p}$ were noticed before and during estrus in HRG only (0.32 $\mathrm{ng} / \mathrm{ml}$ average mean values). After that the value increased up to $1.49 \mathrm{ng} / \mathrm{ml}$ i.e. 2.27 fold increase. With regard to e (table 2) 1.21 fold increase was noticed in the low response group during the last 2 days of treatment, after the end of estrus. Both of these findings correlated well with the success or failure of superovulation protocol in buffalo heifers respectively. Such observation reflects the role of e and $\mathrm{p}$ profiles in the success of superovulation. In harmony with these results, Roy and Parkash (2008) reported that plasma $\mathrm{p}$ concentration in Murrah 
buffalo heifers was basal $(0.2 \pm 0.001 \mathrm{ng} / \mathrm{ml})$ during the peri-estrus period and increased to a peak level on day $13.0 \pm 2.0$ of the cycle. It seems possible that the physiological status of the animal at the start of superovulation, especially with regard to ratio between e and p concentrations, played a major role in the response of the ovaries to the treatment and low $\mathrm{p}$ accompanied with high e give the best results.

In high response group, the superovulated heifers reacted more satisfactory with the FSH gonadotropin treatment since the levels of e were higher, during injections, than other groups. Such high levels of e may be required for the full growth of the developed follicles and as well for their ovulations and CL formations.

As a major conclusion from the present work, week response of the ovaries for superovulation is expected to occur when the animal has a high concentration of $\mathrm{p}$ at the beginning of the regime. Moreover, estimation of e at the day of embryo collection (Day 6 in buffalo heifer) can be used as a criterion to predict the success of superovulation and high levels pointed to low ovarian response.

\section{ACKNOWLEDGEMENT}

The present investigation is a part of research project funded by AID (State Agency Identification Number: MD 900725-7812-360201). The authors express their sincere thanks to this Organization and to Prof. Dr. Walter Williams, Department of Animal Science, Maryland University, USA, for his help in supporting this project.

\section{REFERENCES}

Beg, M.A.; Sanwal, P.C. and Yadav, M.C. (1997): Ovarian response and endocrine changes in buffalo superovulated at mid-luteal and late luteal stage of the estrous cycle: A preliminary report. Theriogenology, 47: 423-432.

Donaldson, L.E. (1985): Estimation of superovulation response in donor cows. Vet. Rec, 13, 117: 33-34.

Drost, M. (2007): Advanced reproductive technology in the water buffalo. Theriogenology, 68, 3: 450-3.

El-Sherry, T.M. (2003): Follicular dynamics and ovarian changes in cycling and superovulated buffaloes. M. V. Sc., Fac. Vet. Med., Assiut University, Egypt.

El-Sherry, T.M.; Matui, M.; Kida, K.; Miyamoto, A.; Megahed, G.A.; Shehata, S.H. and Miyake, Y-I. (2010): Ovarian stimulation with folliclestimulating hormone under increasing or minimal concentration of progesterone in dairy cows. Theriogenology, 73: 488-495.
El-Sherry, T.; Matsui, M. and Miyake, Y-I. (2011): Haemodynamic changes of the superovulated corpus luteum in cattle. Chapter 7, p 169, In: Dairy Cows, Russell E. Mark. Ed., Nova Science Publishers, Inc.

Fuentes, S. and De La Fuente (2000): Holstein superovulatory responses in commercial dairy herds treated with estradiol-17 $\beta$ and progesterone on different days of intravaginal progestagen treatment. Theriogenology, 53, 1: 497.

Gibbons, J.R.; Wiltbank, M.C. and Ginther, O.J. (1999): Relationship between follicular development and the decline in the folliclestimulating hormone surge in heifers. Biol. Reprod. 60: 72-7.

Ginther, O.J.; Bergfelt, D.R.; Kulick, L.J. and Kot, K. (2000): Selection of the dominant follicle in cattle: Role of estradiol. Biol. Reprod. 63: 383-9.

Gradela, A.; Esper, C.R. and Silva e Rosa, A.A.M. (1996): Plasma concentrations of progesterone, 17 B-oestradiol and androstenedione and superovulatory response of Nelore cows (Bos indicus) treated with FSH. Theriogenology, 45: 843-850.

Greve, T.; Callesen, H. and Hyttel, P. (1983): Endocrine profiles and egg quality in the superovulated cows. Nord. Vet. Med. 35: 408-421.

Ismail, S.T.; Essawy, S.A. and Abdoon, A.S.S. (1992): Plasma estrogen and progesterone concentrations in relation to embryo yield in superovulated buffaloes. Vet. Med. J. 40, 3: 53-61.

Lindsell, C.E.; Murphy, B.D. and Mapletoft, R.J. (1986): Superovulation and endocrine responses in heifers treated with FSH-P at different stages of estrous cycle. Theriogenology, 26: 209-219.

Madan, M.L.; Parkash, B.S.; Jaikhani, S.; Singla, S.K.; Palta, P. and Manok, R.S. (1993): Buffalo endocrinology with special reference to embryo transfer. Nat. Dairy Res. Inst., Karnal, India, Publ. 265.

Madan, M.L.; Das, S.K. and Palta, P. (1996): Application of reproductive technology to buffaloes. Anim. Reprod. Sci., 42: 1-4.

Mervat, S. Hassan (2007): Some biochemical studies on follicular fluid contents of Slaughtered buffaloes as related to various reproductive conditions. M.Vet. Sci., Fac. Vet. Med., Assiut Univ., Assiut, Egypt.

McEvoy, T.G.; Broadbent, P.J.; Gebbie, F.E.; Dolman, D.F.; Watt, R.G. and Higgins, L.G. (1996): Progesterone profiles and superovulatory responses of Simmental heifers in relation to pre-ovulatory energy intake and progesterone priming treatment. Theriogenology, 45: 330-330. 
Kafi, M. and McGowan, M.R. (1997): Factors associated with variation in the superovulatory response of cattle. Anim. Reprod. Sci. 48: 137-157.

Misra, A.K.; Jaiswal, R.S.; Kasiraj, R.; Mutha-Rao, M.; Ranga Reddy, N.S. and Pant, H.C. (2000): Preovulatory steroids hormone profiles during unstimulated and superovulatory oestrus cycle in buffalo (Bubalus bubalis). Buffalo J., 3: 371-380.

Mohammed, K.M.E. (2000): Effect of repeated superovulation on ovarian response and embryo recovery in buffaloes. $12^{\text {th }}$ Ann. Congr. Egyptian Soc.16-18 January, p 57-65.

Pant, H.C. (2000): Preovulatory steroids hormone profiles during unstimulated and superovulatory oestrus cycle in buffalo (Bubalus bubalis). Buffalo J., 3: 371-380.

Osman, A.M.; Shehata, H.M. and Megahed, G.A. (2001): Superovulatory response and embryo recovery in buffalo heifers and cows treated with FSH (SUPER- OV) and LH. Vet. Med. J. Giza, 49, 3: 483-491.

Papa, P.C.; Moura, C.E.; Artoni, L. P.; Fatima, L.A.; Campos, D.B.; Marques, J.E. Jr.; Baruselli, P.S.; Binelli, M.; Pfarrer, C. and Leiser, R. (2007): VEGF system expression in different stages of estrous cycle in the corpus luteum of non treated and superovulated buffalo. Domest. Anim. Endocr. 33, 4: 379-89.

Presicce, G.A.; Senatore, E.M.; Bella, A.; De Santis, G.; Barile, V.L.; De Mauro, G.J.; Terzano, G.M.; Stecco, R. and Parmeggiani, A. (2004): Ovarian follicular dynamics and hormonal profiles in heifer and mixed-parity Mediterranean Italian buffaloes (Bubalus bubalis) following an estrus synchronization protocol. Theriogenology, 61, 7-8: 1343-55.

Roberge, S.; Reiger, D. and Rawlings, N.C. (1995): Periovulatory LH, FSH and steroid hormone profiles in superovulated and unstimulated holstein heifers. Theriogenology, 44: 59-70.

Roy, K.S. and Parkash, B.S. (2008): Plasma progesterone, oestradiol-17 alfa and total estrogen profiles in relation oestrous behavior during ovulation in Murrah buffalo heifers. Anim. Physiol. Anim, Nutr. (Berl), 21 May (PubMed).

Sunilchandra, U.; Karayana, K.; Ravindra, J.P.; Ramachandra, S.G. and Honnegowda (2001): The effect of buffalo follicle-stimulating hormone on the Ovarian follicular activity of buffaloes. Buffalo J. 3: 351-60.

Snedecor, G.W. and Cochran, W.G. (1980): Statistical Method. $7^{\text {th }}$ ed. Iowa State Univ. Press, Ames., USA.

Uoc, N.T.; Long, D.D.; Ty, Le van, Chupin, D.; Renard, J.P. and Nguyen, B.X. (1997): Effects of estradiol-17 $B$ and hCG supplementation on superovulatory Response and embryo quality in swamp buffalo (Bubalus bubalis) implanted with norgestomet. Anim. Reprod. Sci., 47: 181-187.

Ullah, N.; Wright, Jr.R.W.; Mehmood, N. and Baig, S.M. (1992): Endocrine profile in relation to ovarian response, recovery rate and quality of embryos in Nili-Ravi buffaloes. Buffalo J. 8, 1 : 47-56.

صورة الاستروجين والبروجستيرون فى شابات الجاموس خلال التبويض الفائق مع الاستجابة العالية والمنخفضة

$$
\text { أحمد معدوح حامد عثمان ، شحاته حسن محمد شحاته }
$$

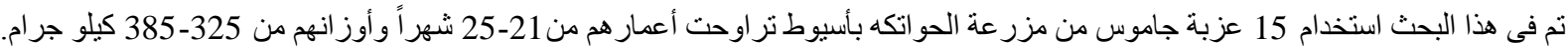

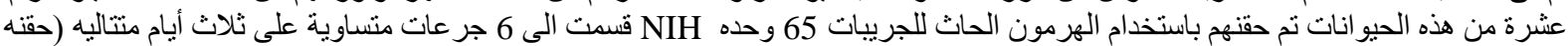

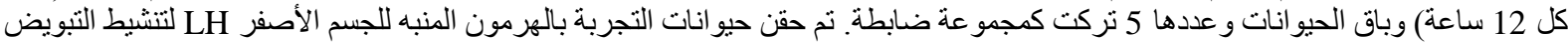

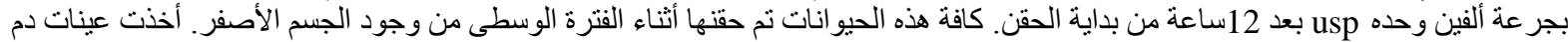

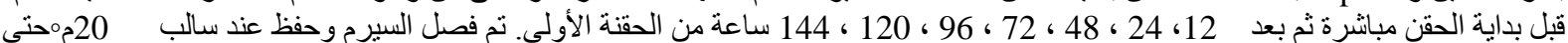

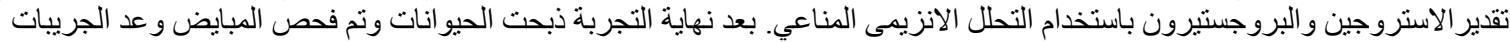

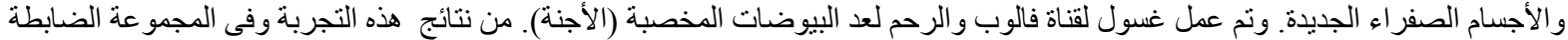

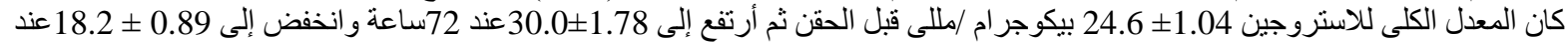

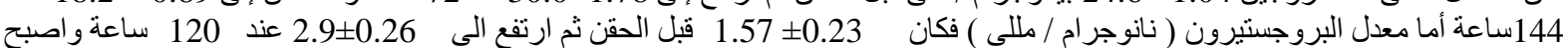

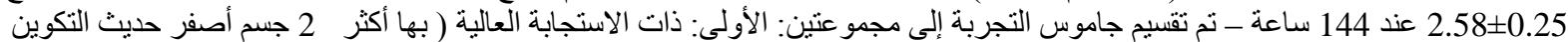

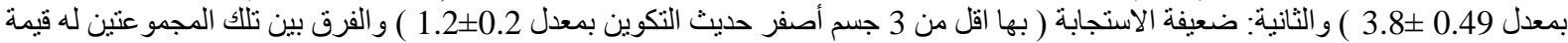

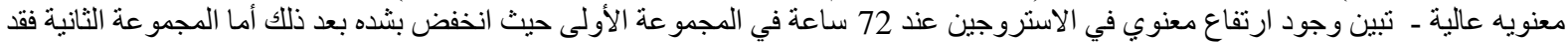

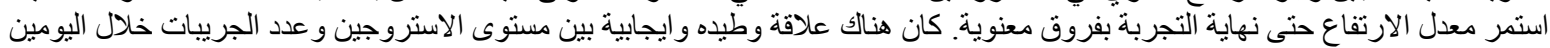

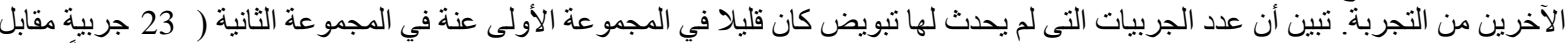

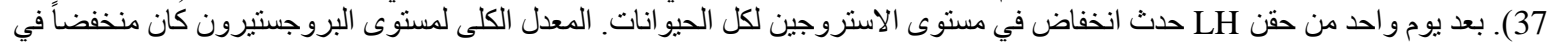

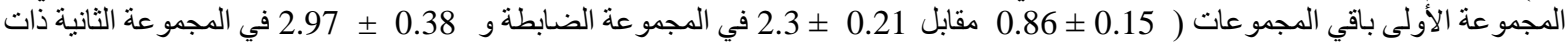

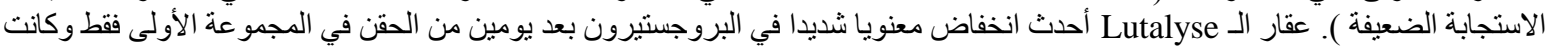

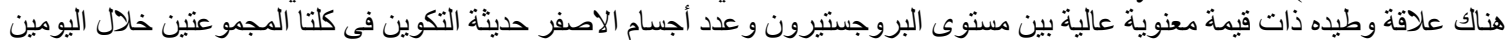

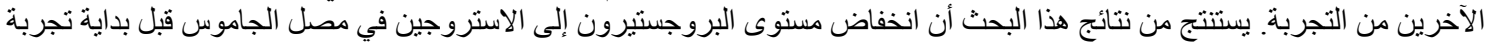
التبويض الفائق له دور في توقع ارتفاع نسبة نجاح استجابة المبايض للتبويض. للناض. 